Jpn. J. Oral Biol., $32: 671-685,1990$.

\title{
ヒト唾液中のヒスタチンに関する研究
}

一一分離，精製とヒスタミン遊離——

\author{
緒 方 憲一 郎 \\ 岡山大学菌学部口腔外科学第 1 講座 (主任 : 西嶋克巳教授)
}

〔受付: 平成 2 年 6 月 27 日〕

\section{Histatins, a family of histidine-rich polypeptides in human saliva; isolation and histamine-releasing activity}

\author{
Ken-ichiro Ogata \\ Department of Oral and Maxillofacial Surgery I. Okayama University \\ Dental School. 2-5-1 Shikata-cho, Okayama 700 \\ (Chief : Prof. Katsumi Nishijima) \\ 〔Accepted for publication: June 27. 1990`
}

Key words : Human saliva/histatins/heparin/histamine release/mast cells

\begin{abstract}
Histidine-rich polypeptides with histamine-releasing activity from rat peritoneal mast cells were isolated from human saliva by heparin-Ultrogel affinity chromatography and reverse-phase high performance liquid chromatography (HPLC). The amino acid composition of these peptides showed high proportions of histidine, lysine and arginine. The amino acid sequences determined by automated Edman degradation revealed that these peptides were completely identical to histatins 1,3 and 5 , respectively. Histatins 3 and 5 induced the histamine release from isolated rat mast cells accompanied with degranulation in a dose-dependent manner over the concentration range $5.40, " \mathrm{M}$, while histatin 1 was weakly active. The histamine release by histatin 5 was completed within 10 sec at $37^{\circ} \mathrm{C}$. The temperature optimum for histatin 5 -induced histamine release was in the range of $25-37^{\circ} \mathrm{C}$, and the release was suppressed at temperature below $15^{\circ} \mathrm{C}$ and above $45^{\circ} \mathrm{C}$. This activity was observed at acid to neutral $\mathrm{pH}$ 's in the medium, but decreased at alkaline $\mathrm{pH}$ 's. Their actions did not require extracellular calcium. This histamine release was not accompanied by leakage of lactate dehydrogenase. These results indicate that histatins 1,3 and 5 can be isolated rapidly from human saliva by using a heparin column and HPLC, and that histatin 5 induces histamine release by means of calcium-independent exocytosis from the mast cells. It is suggested that histatins may possibly play a role in an early stage of inflammation in the oral cavity as naturally occurring host-defensive substances.
\end{abstract}

\section{緒言}

唾液には食物の化学的消化作用や咀嚼, 味覚, 䲆下および発音の補助作用，あるいは洗浄，中和 作用による口腔粘膜の保護作用, 有害物質の排泄 作用および喠液中の酵素や免疫グロブリンなどに よる抗菌作用など多くの生理作用があり, これら

（广700）岡山市鹿田町 2-5-1
の作用は口腔内環境を維持 (oral homeostasis) す るのに役立っている(1,2)。

唾液中には蛋白質, 脂質, 糖質および尿素など の有機成分や電解質，塩などの無機成分のほかに 細胞成分や微生物が含まれている ${ }^{2}$ 。そのうち蛋 白質やベプチド類は種類も多く，現在電気泳動的 に40種類以上の存在が認められている ${ }^{3)}$ 。しかし， これらの蛋白質やペプチド類で生理的な機能が 明 
らかにされているものは非常に少なく4， 上記の 唾液の生理作用との関係についても不明の点が多 い。

近年ヒト唾液中にユニークなアミノ酸組成を持 つペプチド群があることが見いだされてきだ”。 これらのペプチド類はそれぞれプロリン，ヒスチ ジンおよびチロシンなどのアミノ酸を異常に多く 含んでいることが特微的であり，またこれらはヒ ドロキシアパタイトに強い親和性を持っているた め，歯の表面の獲得被膜形成に関与するぺプチド

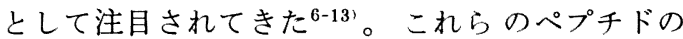
うち，現在一次構造が解明されているものには proline-rich protein (PRPs) ${ }^{14,15}$ （高プロリン含 有ペプチド類)， statherin ${ }^{13)}$ （高チロシン含有 ゚゚ プチド)，および本研究の対象であるヒスタチン

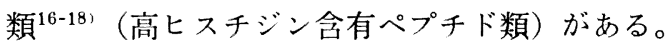

ヒスタチン類は唾液中に分泌されるヒスチジン に富んだ分子量 $3,000 \sim 5,000$ 程度の一群のポリペ プチドであり，これらは1970年代初めにヒト耳下 腺唾液中に打いて遺伝的に多形性を示す塩基性の

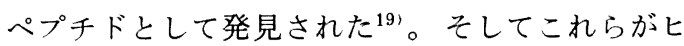
卜を含む霊長類にのみ存在し ${ }^{201}$ ，分子内にヒスチ

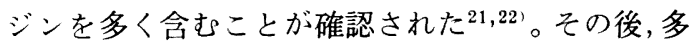
くの研究者によって様々な分離, 精製法が試みら $れ^{23-30)}$, parotid basic protein $(\mathrm{Pb})$, post-parotid basic protein $(\mathrm{PPb})^{19-22)}$ や histidine-rich polypeptides $(\mathrm{HRPs})^{10,25)}$ などの名称が提唱され混乱 していた。これは，ヒスタチン類が類似の大きさ と組成を持つ低分子ペプチドの集団として 存在す ることや，非常に塩基性の強いものを含むことに 加えて，精製の指標となる適当な生物活性がなか ったため，それらの分離と精製が困難であったこ とが原因と考えられる。1988年になって，Oppenheim ら ${ }^{17}$ はこれらのペプチドの主要な成分を 分 離, 精製することに成功し，これらのペプチド群 に対して“ヒスタチン”と命名し，名称を統一し た。

現在電気泳動的に12種類のヒスタチン類が 認め られており，一次構造が決定されている(18)。これ らはすべて類似のアミノ酸組成を持ち，そのうち ヒスタチン $1 ， 3$ および 5 のつの ペプチドで 唾液中の総ヒスタチン量の $85 \sim 90 \%$ を占めてい
$る^{17)}$ 。

これらヒスタチン類の生物活性に関しては長い 間明らかにされていなかったが，最近になって in vitro においてヒスタチン類が $C$. albicans に 対する抗真菌作用 ${ }^{16,17,31-33)}$ および $S$. mutans に 対する抗菌作用 ${ }^{34,35)}$ を示すことが報告された。こ れらの知見からヒスタチン類は唾液中の自然の殺 菌物質として，口腔内において生体防御作用に役 立っていることが示唆されている。

一方, Sugiyama ら ${ }^{36,371}$ はヒト唾液がラット肥 満細胞からヒスタミン（Hi）を遊離することを見 いだし，唾液中から $\mathrm{Hi}$ 遊離活性ペプチド（F-A） を分離，精製し，その一次構造を明らかにした。 このペプチドは分子内にヒスチジン残基を多量に 含有するポリペプチドであり，アミノ酸組成は HRPs の1つに非常に類似していたため, HRPs との関連に興味が持たれていた。このペプチド は，後に Oppenheim ら ${ }^{17)}$ の報告によって，彼ら の提唱するヒスタチン 5 と同一のものであること が明らかとなった。そこで本研究は，従来ヒ卜唾 液からの分離と精製が極めて困難であったヒスタ チン類を, $\mathrm{Hi}$ 遊離活性を指標として，ヘパリンア フィニティークロマトグラフィーと高速液体クロ マトグラフィーを用いて，迅速，かつ高収率に分 離，精製することを可能にした。またこれらヒス タチン類の口腔生物学的な意義を明らかにするこ とを目的として，ヒスタチン類によるラット肥満 細胞からの Hi 遊離機構について詳細に検討した。

\section{材料および方法}

\section{1. 実験動物}

体重300 350g の雄性 W istar 系ラットを使用 した。

\section{2. 唾液}

クエン酸刺激によって同一人から得た 混合唾液 を用いた。唾液は久保木の方法 ${ }^{38)}$ を用いて採取 後，ただちに酢酸で $\mathrm{pH} 3 \sim 4$ に調製し $-20^{\circ} \mathrm{C}$ 以下に貯蔵した。

\section{3. 肥満細胞}

肥満細胞はラットの腹腔内細胞 ${ }^{39}$ から Percoll を用いた重層遠心法 ${ }^{40}$ によって分離した。ラット をエーテル麻酔下に頸動脈を切断，脱血致死さ 
せ，その腹腔内に $37^{\circ} \mathrm{C}$ に加温した生理的塩溶液 (PS)（組成：154mM NaCl，2.7mM KCl, 0.9

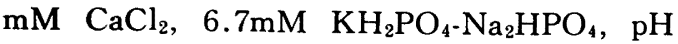
7.2） $15 \mathrm{ml}$ を注入し, 腹部を 90 秒間軽くマッサー ジしてから腹部正中線に沿って切開し，腹水をピ ペットで採取した。これを $45 \times \mathrm{g}$ で 3 分間遠心し て腹腔内細胞を得た。細胞は $0.01 \%$ 牛血清アルブ ミンを含む PS (PSB) に浮遊させ遠心操作によ って 2 回洗浄した。この細胞を $1.6 \mathrm{ml}$ の PSB に 浮遊させ， $1.5 \mathrm{M}$ の $\mathrm{NaCl}$ を含む $90 \%$ Percoll $4 \mathrm{~m} l$ と混和しその上部に $1 \mathrm{~m} l$ の $\mathrm{PSB}$ を重層 して $4{ }^{\circ} \mathrm{C}$ において 15 分間 $200 \times \mathrm{g}$ で遠心した。遠 心管の底部に集まった肥満細胞を他の細胞から分 離し，精製した肥満細胞を得た。肥満細胞の純度 は90\%以上であった。得られた細胞は PSB で 2 回洗浄したのち実験に用いた。

4. ヒスタチン類の調製

唾液からのヒスタチン類はへパリンのアフィニ ティークロマトグラフィー ${ }^{41}$ と逆相高速液体ク口 マトグラフィー（HPLC）によって分離，精製し た。酢酸で $\mathrm{pH} 3.5$ に調製したヒト唾液を $100^{\circ} \mathrm{C}$ で 5 分間加熱した後, $4{ }^{\circ} \mathrm{C}$ において $10,000 \times \mathrm{g}$ で30分間遠心した。その上清を $2 \mathrm{M}$ Tris で $\mathrm{pH}$ 7.0に調製し，0.01M Tris- $\mathrm{HCl}$ 緩衝液 $(\mathrm{pH} 7.0)$ で 3 倍に希釈した。この試料を $0.01 \mathrm{M}$ Tris- $\mathrm{HCl}$ 緩衝液 (pH 7.0) で平衡化した heparin-Ultrogel カラム $(\mathrm{LKB}$ 社製， $1.5 \times 80 \mathrm{~mm})$ に吸着させ, $200 \mathrm{~m} l$ の同緩衝液と $1.5 \mathrm{M}$ の NaCl を用いて直線 濃度勾配法によって 溶出した。溶出成分は試験管 あたり $5 \mathrm{~m} l$ ずつ分画し，それぞれ $235 \mathrm{~nm}$ におけ る吸光度によって測定した。ヒスタチンを含む分 画はヒスタミン遊離活性を指標にして採集し，脱 塩, 凍結乾燥したのち逆相 HPLCによって精製 した。逆相 HPLC は Chemcosorb 5-ODS-H $(7.5 \times 250 \mathrm{~mm})$ のカラムを用い $0.05 \%$ のトリフル オロ酢酸（TFA）を含む10\%アセトニトリルと 0.05\% TFA を含む50\%アセトニトリルで50分間 の直線濃度勾配法によって 流速 $1.5 \mathrm{~m} l / \mathrm{min}$ で溶 離した。

\section{5. アミノ酸分析および一次構造}

逆相 HPLC によって精製したヒスタチン類は それぞれ減圧下に $6 \mathrm{~N} \mathrm{HCl}$ 中で $110^{\circ} \mathrm{C}, 24$ 時間加
水分解した後，日立高速自動アミノ酸分析機を使 用してアミノ酸分析を行った。

アミノ酸配列は Applied Biosystem model 835 シークェンサーを用い, 自動 Edman 分解 ${ }^{22} に よ$ って行った。C末端のアミノ酸残基はカルボキシ ペプチダーゼAを用いて分解して確認した。 PTH-アミノ酸の測定は Applied Biosystem model 120A PTH-分析機を用いて行った。

ホスホセリンの確認はヒスタチン1をトリプシ ンで分解して得られた $\mathrm{N}$ 末端の 1 位から 6 位まで のペプチド（T-1）を減圧下に $6 \mathrm{~N} \mathrm{HCl}$ 中で $110^{\circ} \mathrm{C} ， 2$ 時間加水分解した試料について行った。

6. $\mathrm{Hi}$ 遊離活性の測定

分離した 肥満細胞の浮遊液 $\left(10^{5}\right.$ 細胞 $\left./ \mathrm{m} l\right) \quad 0.5$ $\mathrm{ml}$ を $37^{\circ} \mathrm{C}$ で 5 分間保温したのちヒスタチン類を 加えて 10 分間反応させた。反応は $1.5 \mathrm{~m} l$ の水冷し

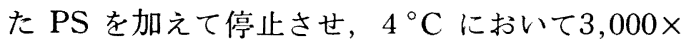
$\mathrm{g}, 15$ 分間遠心した。その上清㧍よび沈渣を分離し それぞれに0.1N になるように $\mathrm{HCl}$ を加え，100 ${ }^{\circ} \mathrm{C}$ で 3 分間加熱したものを $\mathrm{Hi}$ 定量の試料とし た。

$\mathrm{Hi}$ 遊離の時間経過の測定は反応液の 10 倍容量 の氷冷 PS を加えて反応を停止させた ${ }^{43}$ 。この方 法によって短い反応経過の測定ができた。

$\mathrm{Hi}$ 遊離の $\mathrm{pH}$ の影響を測定するために $\mathrm{pH}$ 4.0〜8.0の範囲ではリン酸緩衝液， $\mathrm{pH} 8.5 \sim 9.0$ の場合は N-[2-hydroxyethyl] piperazine-N-2ethanesulfonic acid (HEPES) - $\mathrm{NaOH}$ 緩衝液100 $\mathrm{mM}$ を用いて行った。

7. Hi の定量

Hi の定量は Shore らの螢光法 ${ }^{44}$ によって行っ た。 $3.0 \mathrm{~m} l$ の試料に $1 \mathrm{~N} \mathrm{NaOH}$ を $0.6 \mathrm{~m} l$ 加え, メタノールに溶かした $0.15 \mathrm{ml}$ の0.5\% o-フタル アルデヒドを加え室温で 4 分間反応させた。反応 後, $0.3 \mathrm{~m} l$ の $2 \mathrm{M}$ クエン酸を加えて励起波長 358 $\mathrm{nm}$ ，䖝光波長 $446 \mathrm{~nm}$ で測定した。Hi 遊離は下 式に従って細胞に含まれる総 $\mathrm{Hi}$ 量に対する上清 の $\mathrm{Hi}$ 量の\%として表した。

$\mathrm{Hi}$ 遊離率 $=\frac{\text { 上清の } \mathrm{Hi} \text { 量 }}{\text { 上清の } \mathrm{Hi} \text { 量+沈渣の } \mathrm{Hi} \text { 量 }} \times 100$ $\mathrm{ED}_{50}$ は, 最大の $\mathrm{Hi}$ 遊離の $50 \%$ を示す七ス夕 チンの濃度を，濃度と遊離率の関係から簡易的に 
グラフから求めた。

8. 乳酸脱水素酵素 $(\mathrm{LDH})$ の測定

LDH の测定は Roy のの方法 ${ }^{45)}$ に従って行っ た。 $\mathrm{Hi}$ 遊離反応後, 遠心して得た上清 $0.5 \mathrm{~m} l$ に $1 \mathrm{mM}$ NAD $0.5 \mathrm{~m} l$ 加え, その反応液 $0.5 \mathrm{~m} l$ に $5 \mathrm{mM}$ 乳酸を $50 \mu l$ 加えた。他の $0.5 \mathrm{ml}$ は対照 として脱イオン水 $50 \mu l$ を加えそれぞれ $25^{\circ} \mathrm{C}$ で 20 分間保温した。反応後脱イオン水をそれぞれ 2.5 $\mathrm{m} l$ ずつ加えた後，励起波長340nm，螢光波長 460 $\mathrm{nm}$ における螢光強度を測定した。

$\mathrm{LDH}$ の遊離は， $0.01 \%$ Triton X-100を肥 満細胞浮遊液に添加した場合の遊離を $100 \%$ とし て計算した。

\section{結果}

1.ヒスタチン類の精製

ヒト唾液をへパリンカラムにかけると，唾液中 の $\mathrm{Hi}$ 遊離活性は認めiれなくなる。これは，唾 液中の $\mathrm{Hi}$ 遊離成分がへパリンに吸着されること によるものと考えられた。そこで， $\mathrm{NaCl}$ の直接 濃度勾配法によってこれを溶出すると $\mathrm{A}, \mathrm{B}$ およ びCの3つの分画に分かれた（Fig. 1)。肥満細 胞からの $\mathrm{Hi}$ 遊離活性は $\mathrm{B}$ と C 分画に認められ たが，Aの分画には認められなかった。

$\mathrm{A} ， \mathrm{~B}$ およびCの分画について脱塩後，それぞ れについて逆相 HPLC を行うと Fig. 2 に示す パターンが得られた。 $\mathrm{Hi}$ 遊離活性のある B 分画 は 2 つピークに分かれたが最初のピーク， H-1 にのみ $\mathrm{Hi}$ 遊離活性が認められた。C 分画は多数

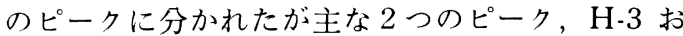
よび $\mathrm{H}-5$ に $\mathrm{Hi}$ 遊離活性が認められた。 $\mathrm{H}-1$, H-3 および H-5 の分画を集め，それぞれ凍結 乾燥して $\mathrm{Hi}$ 遊離およびアミ，酸分析の試料とし た。収量は喠液 $200 \mathrm{ml}$ 当たり, 総ペプチド量 $19 \mathrm{mg}$ であり，H-1，3 および 5 の構成比は $1 ： 1 ： 2$ であった。

2. ヒスタチンの一次構造

H-1，3 および 5 についてそれぞれのアミ/酸 分析 (Table 1)，および自動 Edman 分析法か ら推定される一次構造を Fig. 3 に示す。

$\mathrm{H}-1 ， 3$ および 5 のアミノ酸残基の数はそれぞ れ38，32および24であった。これらのペプチドは

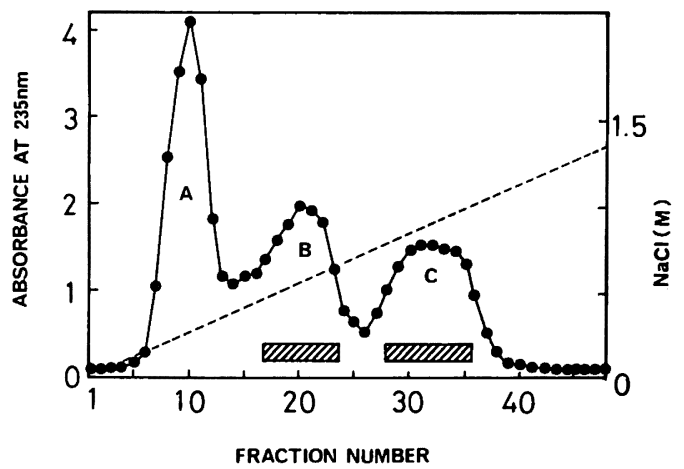

Fig. 1 Elution profile of human saliva proteins from heparin-Ultrogel column equilibrated in $0.01 \mathrm{M}$ Tris- $\mathrm{HCl}, \mathrm{pH} 7.0$. Elution was carried out applying a linear gradient $0-1.5 \mathrm{M} \mathrm{NaCl}$ in the same buffer. $5 \mathrm{ml}$ frations were collected and the eluate was monitored for absorbance at $235 \mathrm{~nm}$. Hatched area represents histamine-releasing activity.

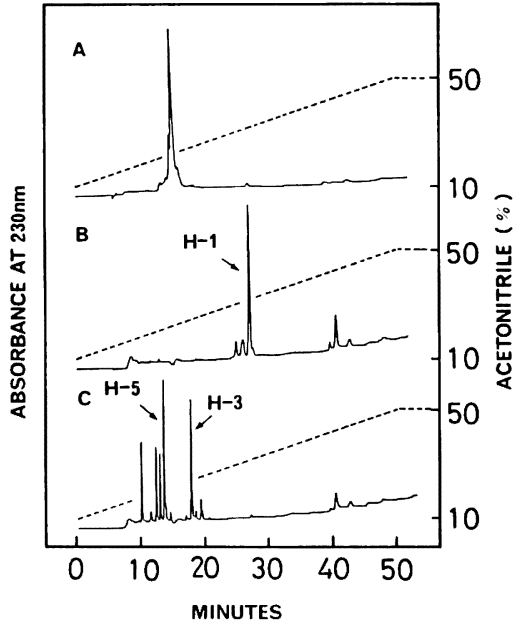

Fig. 2 Reverse-phase HPLC of fractions eluted from heparin-Ultrogel column. The sample was applied to a column (Chemcosorb 5-ODS-H) and a linear gradient $10-50 \%$ acetonitrile in $0.05 \%$ trifluoroacetic acid was applied for $50 \mathrm{~min}$. The flow rate was $1.5 \mathrm{ml} / \mathrm{min}$.

それぞれヒスチジン残基を分子内に 7 つ含んでい た。H-3 と H-5 の末端の 1 位から24位までのア ミノ酸配列は同じであり，H-1 は 4 位の Glu と 11位の Arg を除いて22位までは H-5 の構造と 同じであった。また H-1 の32 38位と H-3 の 
26 32 位の 構造 も同じであった。 H-1 のN末端 の 2 位の Ser はリン酸基を持つ phosphoserine (Pse) であった。これに対し，H-3 と H-5 には

Table 1 Amino acid composition of $\mathrm{H}-1,3,5$ and tryptic peptide of $\mathrm{H}-1$ ( $\mathrm{T}-1$ : Asp-Ser-His-Glu-Lyse). Values in parenthesis are data identified by automated Edman degradation.

\begin{tabular}{lllll}
\hline $\begin{array}{l}\text { Amino } \\
\text { acid }\end{array}$ & $\mathrm{H}-1$ & $\mathrm{~T}-1$ & $\mathrm{H}-3$ & $\mathrm{H}-5$ \\
\hline Asp & $5.6(5)$ & $1.4(1)$ & $3.5(4)$ & $1.2(1)$ \\
Ser & $2.7(3)$ & $1.2(1)$ & $2.5(3)$ & $1.8(2)$ \\
Glu & $3.4(3)$ & $1.3(1)$ & $1.0(1)$ & $1.0(1)$ \\
Pro & $1.1(1)$ & 0 & 0 & 0 \\
Gly & $3.1(3)$ & 0 & $2.1(2)$ & $2.3(2)$ \\
Ala & 0 & 0 & $1.0(1)$ & $1.3(1)$ \\
Leu & $1.0(1)$ & 0 & $1.1(1)$ & 0 \\
Tyr & $5.3(5)$ & 0 & $3.7(4)$ & $2.6(2)$ \\
Phe & $3.2(3)$ & 0 & $1.3(1)$ & $1.2(1)$ \\
Lys & $2.9(3)$ & $0.8(1)$ & $4.3(4)$ & $4.3(4)$ \\
His & $7.0(7)$ & $1.0(1)$ & $7.0(7)$ & $7.0(7)$ \\
Arg & $4.0(4)$ & $1.3(1)$ & $4.0(4)$ & $3.1(3)$ \\
\hline Total & 38 & 6 & 32 & 24 \\
\hline
\end{tabular}

リン酸基は存在しなかった。H-5 の構造はすでに Sugiyama $5^{37)}$ が報告した唾液ペプチド，F-A と同一であり，H-1 および H-3 は Oppenheim らの報告しているヒスタチン 1 と 3 に完全に一致 していた ${ }^{16,17}$ 。

3. ヒスタチン類による $\mathrm{Hi}$ 遊離

a) 用量依存性

ヒスタチン類（H-1，3 および 5 ）はFig. 4 に 示すようにラット分離肥満細胞から $5 \mu \mathrm{M}$ から $150 \mu \mathrm{M}$ の濃度範囲において用量依存的に $\mathrm{Hi}$ を 遊離した。H-3 および $\mathrm{H}-5$ はほぼ同程度の $\mathrm{Hi}$ 遊離活性を示し，それらの $\mathrm{ED}_{50}$ は約 $15 \mu \mathrm{M}$ で あった。一方，H-1 の $\mathrm{ED}_{50}$ は約 $100 \mu \mathrm{M}$ であり， $\mathrm{H}-3$ および H-5 に比較して $\mathrm{Hi}$ 遊離活性は弱か った。

b) $\mathrm{Hi}$ 遊離の時間経過

$37^{\circ} \mathrm{C}$ において $\mathrm{H}-5$ による $\mathrm{Hi}$ 遊離は 10 秒以 内に最大に達した（Fig. 5 )。反応時間 5 秒後の 時点ですでに約 $80 \%$ の $\mathrm{Hi}$ 遊離が起こり，10秒後 に反応は最大に達した。それ以後の $\mathrm{Hi}$ 遊離には 変化がみられなかった。他のヒスタチンについて も同様の結果であった。

HISTATIN 1

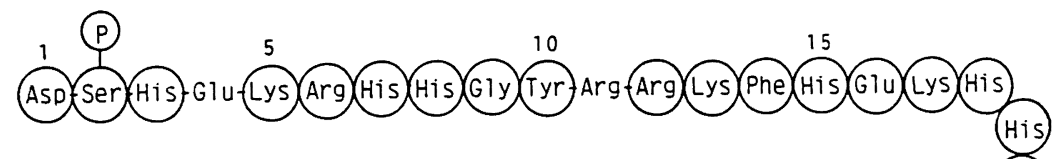

Ser 20

HISTATIN 3
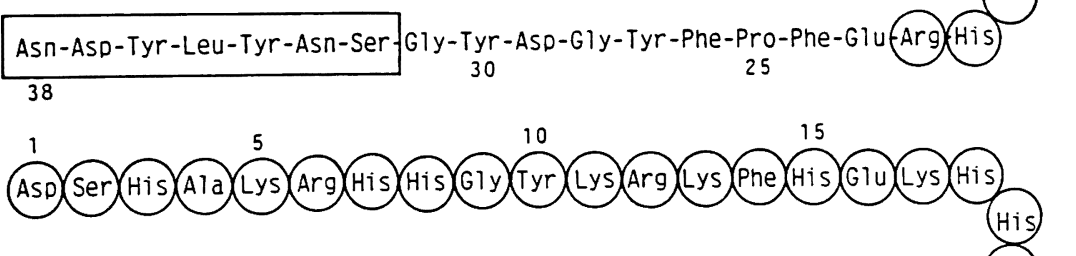

$\operatorname{sen} 20$

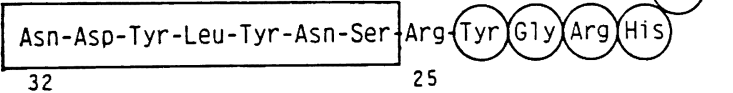

HISTATIN 5

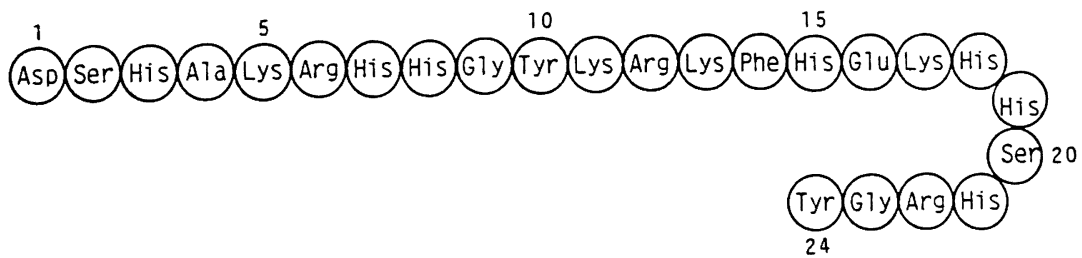

Fig. 3 Amino acid sequences of histatins 1,3 and 5. Identical residues are enclosed by the circle or the solid line. P-Ser represents phosphoserine. 


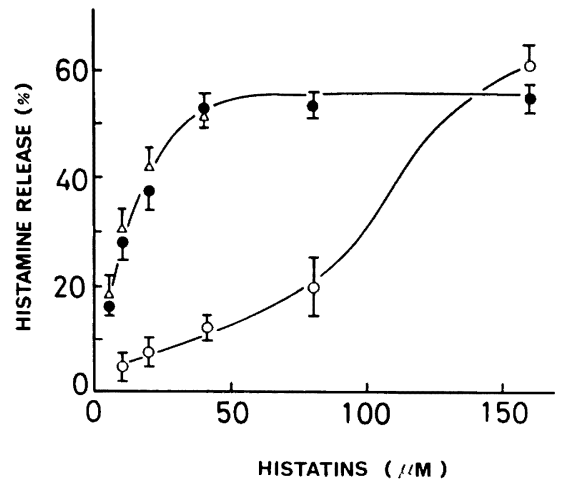

Fig. 4 Histamine release from isolated rat mast cells induced by histatins 1,3 and 5 . Mast cells were incubated for $10 \mathrm{~min}$ at $37^{\circ} \mathrm{C}$ with $\mathrm{H}-1(\mathrm{O}), \mathrm{H}-3(\Delta)$ and $\mathrm{H}-5$ (•). Values represent the mean $\pm \mathrm{S}$. E. of three experiments corrected for spontaneous release.

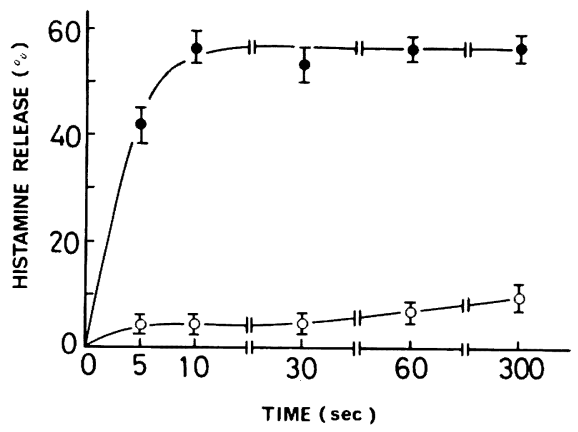

Fig. 5 Time course of histamine release induced by $\mathrm{H}-5$. Mast cells were incubated with $\mathrm{H}-5(40 \mu \mathrm{M})$ (๑) or without H-5 (O) at $37^{\circ} \mathrm{C}$. Values represent the mean \pm S.E. of three experiments corrected for spontaneous release.

c） 反応温度の影響

Fig. 6 は H-5 による $\mathrm{Hi}$ 遊離の温度の影響を 示すもので, この遊離反応の至適温度は $25^{\circ} \mathrm{C}$ か $ら 37^{\circ} \mathrm{C}$ の範囲に存在し, $10^{\circ} \mathrm{C}$ 以下または $45^{\circ} \mathrm{C}$ 以上では反応は抑制された。また，肥満細胞を 45 ${ }^{\circ} \mathrm{C}$ で10分間保温した後, $37^{\circ} \mathrm{C}$ において H-5 を 添加しても $\mathrm{Hi}$ 遊離は起こらず， $45^{\circ} \mathrm{C}$ の保温に よって $\mathrm{Hi}$ 遊離反応は不可逆的に抑制された。

d) $\mathrm{pH}$ の影響

H-5 による Hi 遊離は Fig. 7 に示すように 反応液の $\mathrm{pH}$ が中性から酸性側においては顕著に

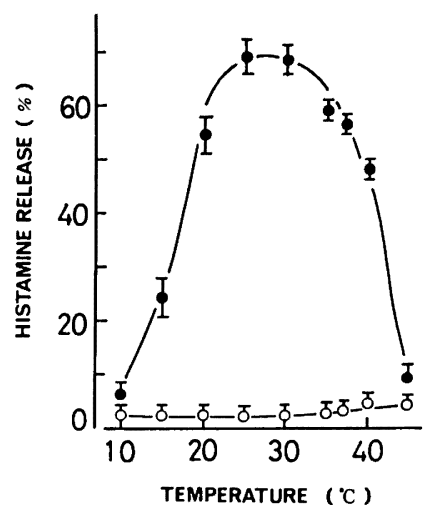

Fig. 6 Effect of temperature on the histamine release induced by $\mathrm{H}-5$. Mast cells were preincubated at various temperatures for $10 \mathrm{~min}$, and further incubation was made for $10 \mathrm{~min}$ with $\mathrm{H}-5(40 \mu \mathrm{M})(\bullet)$ or without $\mathrm{H}-5(\mathrm{O})$. Values represent the mean \pm S. E. of three experiments corrected for spontaneous release.

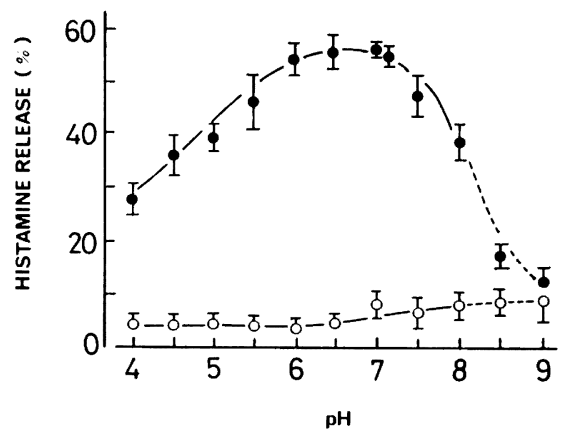

Fig. 7 Effect of $\mathrm{pH}$ on the histamine release induced by $\mathrm{H}-5$. Mast cells were incubated for $10 \mathrm{~min}$ at $37^{\circ} \mathrm{C}$ with $\mathrm{H}-5(40 \mu \mathrm{M})$ $(\bullet)$ or without $\mathrm{H}-5(\mathrm{O})$ in an incubation medium with various $\mathrm{pH}$ 's. Values represent the mean \pm S.E. of three experiments corrected for spontaneous release.

起こったが，アルカリ側では抑制され，Hi 遊離の 至適 $\mathrm{pH}$ は6.5 7.2であった。

e）カルシウムイオンの影響

反応液中の $\mathrm{Ca}^{2+}$ 浱度の $\mathrm{OM}$ から $10^{-3} \mathrm{M}$ の範 囲において $\mathrm{Hi}$ 遊離活性を調べたが，H-5 による $\mathrm{Hi}$ 遊離に対する $\mathrm{Ca}^{2+}$ の影響は認められなかっ た。また $\mathrm{Ca}^{2+}$ を含まない反応液に $1 \mathrm{mM}$ EDTA を加えた場合にも $\mathrm{Hi}$ 遊離に影響は認められなか った (Fig. 8)。 


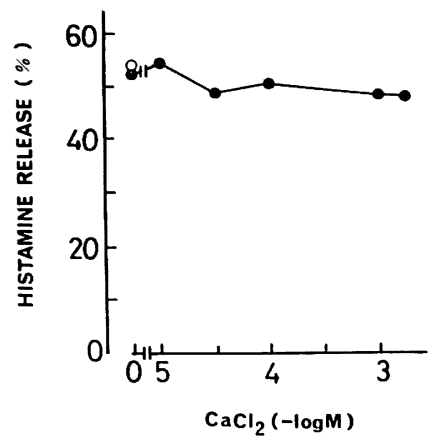

Fig. 8 Effect of extracellular calcium ions on the histamine release induced by $\mathrm{H}-5$. Mast cells were incubated at $37^{\circ} \mathrm{C}$ for $10 \mathrm{~min}$ with $\mathrm{H}-5(40 \mu \mathrm{M})(\bullet)$ in a medium containing $\mathrm{CaCl}_{2}$ at various concentrations, and with $1 \mathrm{mM} \operatorname{EDTA}(\mathrm{O})$. Values represent the mean of two experiments.

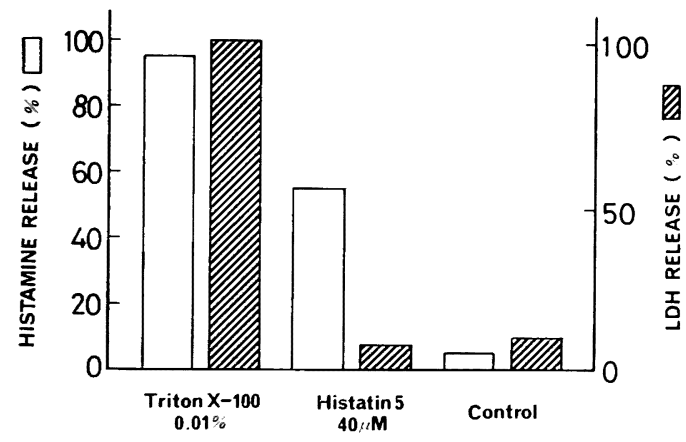

Fig. 9 Release of intracellular LDH accompanied with histamine release induced by $\mathrm{H}-5$. Mast cells were incubated at $37^{\circ} \mathrm{C}$ for $10 \mathrm{~min}$ with $\mathrm{H}-5(40 \mu \mathrm{M})$ and Triton-X $0.01 \%$. LDH was assayed as described in text. Values represent the mean of two experiments.

\section{4. $\mathrm{LDH}$ の遊離に対する影響}

$\mathrm{H}-5$ による肥満細胞からの $\mathrm{Hi}$ 遊離が細胞の 崩壊によるものでないことを確認するために 細胞 質からの LDH の遊離を測定した。その結果, $\mathrm{Hi}$ 遊離に伴う LDH の遊離は認められず，Fig. 9 に示すように H-5 による肥満細胞からの $\mathrm{Hi}$ 遊 離が約 $60 \%$ である場合においても LDH の遊離は 起こらなかった。これに対して細胞の lysis を起 こす Triton-X の場合には $\mathrm{Hi}$ 遊離に伴って LDH の遊離が著明に認められた。

\section{考察}

ヒト唾液成分を電気泳動的に分析する試みは古 くから行われており，Hoerman ${ }^{46)}$, Meyer ら ${ }^{47),}$ および Bellavia ${ }^{48)}$ はヒト唾液を電気泳動するこ とによって塩基性の成分の 存在を認め, Bonilla ら ${ }^{49}$ は，これらの成分が低分子の蛋白質であるこ とを報告している。

Azen ${ }^{19)}$ は， ヒト唾液を尿素存在下に酸性条件 で澱粉ゲル電気泳動を行い，多種類の塩基性蛋白 を分離した。彼はこれらの蛋白を家族的に調查 し，遺伝的に多形性を示すことを見いだした。そ してこれらの蛋白に耳下腺由来の塩基性蛋白質と いう意味で parotid basic protein $(\mathrm{Pb})$ という名 称を提唱した。その後, 彼はこれらの蛋白がヒト を含む霞長類にのみ存在し，犬やラットには認め られないことを報告した ${ }^{201}$ 。以上のことからこれ らの蛋白は人類遺伝学や進化の面から興味が持た れていた。

一方, Balekjian ら ${ }^{231}$ は, 弱酸性のイオン交換 クロマトグラフィーによってヒト耳下腺唾液から 高ヒスチジン含有のペプチドを分離し，これらが ヒストンであることを主張した。これらのペプチ ドはポリアクリルアミド電気泳動において $6 \sim 8$ 本のバンドに分かれ，アミ，酸分析の結果，七ス チジンを17〜30\%含んでいた。

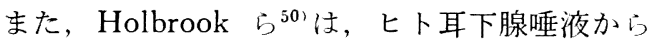
塩基性アミノ酸を $50 \%$ 以上も含む低分子の塩基性 ペプチドを分離し，これらが口腔内細菌の糖分解 活性を上昇させることを報告している。このよう な経過でヒト唾液中の高ヒスチジン含有ペプチ ドの存在が次第に明らかにされてきた。その後, Hay $^{10)}$ によってこれらのペプチドに対して histidine-rich polypeptides (HRPs) という名称が最 初に用いられた。彼はヒト耳下腺唾液から酸性の 高ヒスチジン含有ペプチドを分離し，これがヒド ロキシアパタイトに強い親和性を示すことを見い だした。そしてこのペプチドがエナメル質表面の 獲得被膜 (acquired enamel pellicle) の形成に 関与することを示唆した。

続いて Baum ら ${ }^{25-29}$ 'は塩基性 HRPs の分離に 初めて成功した。彼らはヒト耳下腺唾液からイ才 
ン交換クロマトグラフィーレゲル滤過法により HRPs t分離し, カチオニック電気泳動において HRPs が $1 \sim 7$ までの成分に分かれることを見い

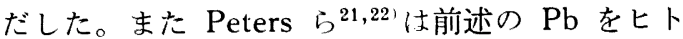
耳下腺唾液から分離するとともに，類似の構造を 示す post- $\mathrm{Pb}$ protein $(\mathrm{PPb})$ を分離した。彼ら は $\mathrm{Pb}$ および $\mathrm{PPb}$ が高ヒスチジン含有ペプチド であることを確認し，また Pbs がさらに4つの 成分に分かれることを報告している。

その後, HRPs の最初の標品が MacKay ら ${ }^{301}$ によって得られた。彼らはイオン交換クロマトグ ラフィーとゲル濾過法によってヒト耳下腺唾液か ら mg の単位で HRPs の粗標品を得ることに成 功した。彼らはこの方法によって唾液 $100 \mathrm{ml}$ から 乾燥重量 $6 \mathrm{mg}$ の HRPs の標品を精製した。し かし，この粗標品は主として HRP-3 および 5 を 含んだ HRP-1〜7 の混合物であり，均一に精製 されたものではなかった。

HRPs の 1 つについて初めて一次構造を明らか

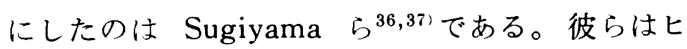
卜耳下腺唾液から肥満細胞に対して $\mathrm{Hi}$ 遊離活性 を有するペプチド，F-A を分離しその一次構造を 報告した。この F-A は高ヒスチジン含有ポリペ プチドであり，その一次構造はその後報告された ヒスタチン 5 (HRP- 5$)^{17)}$ と同一のものであっ た。

近年になって，Oppenheim $ら^{16,17}$ は，ヒト耳 下腺唾液から HRP-1，3 および 5 を分離し，そ れらの一次構造を明らかにした。最初にその一次 構造を報告したのは场下腺唾液からのいわゆ る中性 $\mathrm{HRP}^{16}$ ，であり，この中性 HRP はリン 酸残基を含んでおり溶液中においてリン酸カル シウムの形成を阻害した。それ故，彼らはこの HRP が獲得被膜形成に関与するぺプチドである ことを示唆した。続いて彼ら ${ }^{171}$ は, ヒト耳下腺唾 液を Bio-gel P2 カラムでゲル濾過を行い，唾液 中のすべての HRPs が Bio-gel に非特異的に吸 着され，他の蛋白や塩よりはるかに遅れて溶出さ れることを見いだした。彼らはこの Bio-gel P2 カラムによって得られた分画を逆相 HPLC で 精製し，HRP-1，3 および 5 に関する一次構造か ら従来中性 HRP と言われていたペプチドが
HRP-1 と一致することを確認した。そして従来 から個々の研究者によって分離法や分析法の違い から種々の名称がつけられていた高ヒスチジン含 有ペプチド類に対し，“ヒスタチン”と命名し， 名称を統一した。そして電気泳動上の陽極からの 易動度に従ってヒスタチン類を $1 \sim 7$ まで分類し た。最近彼らはヒスタチン類を $1 \sim 12$ まで精製 し，それらの一次構造を明らかにしている(18)。こ の Bio-gel P2 を用いるヒスタチン類の分離法は 確かに one-step での分離が可能であるが，Biogel に対するヒスタチン類の非特異的な吸着を利 用したものであることやゲル濾過に長時間を要す る欠点がある。

これに対して，本研究のヒスタチン類分離法は 非常に簡便な方法であり，しかも迅速にかつ高収 率な分離を可能にした。

本分離法の特徴は，1） ヘパリンカラムを用い るアフィニティークロマトグラフィーを利用す る，2） Hi 遊離活性を分離, 精製の指標とする, 3）唾液試料を酸性条件下で前もって 短時間加熱 処理することにある。へパリンカラムを唾液中の ヒスタチン類の分離に応用したのは，著者らが血 清アルブミンのペプシン分解物から $\mathrm{Hi}$ 遊離活性 のあるペプチド，P-1 を分離するのに非常に有効 であったことによる ${ }^{41}$ 。Figs. 1，2 に示したよう にへパリンカラムを用いて唾液中のすべてのヒス タチン類を one step で分離することを可能にし た。このへパリンカラムを用いることによって分 離に要する時間を大幅に短縮でき，再現性よく， 高収量にヒスタチン類を分離できる利点がある。

分離, 精製の指標として $\mathrm{Hi}$ 遊離活性を測定す ることはすでに杉山らがヒト唾液中の $\mathrm{Hi}$ 遊離活 性ペプチド, F-A の分離やマウス顎下腺の $\mathrm{Hi}$ 遊 離活性因子の分離に用いた方法を適用したことに よる ${ }^{51,521}$ 。Oppenheim ら ${ }^{17)}$ の報告により，F-A とヒスタチン 5 が同一物質であることが 確認され たので, ヒスタチン類の分離に $\mathrm{Hi}$ 遊離活性を指 標として応用することは有効な手段である。

本研究で著者が行った喠液試料の加熱処理は, 加熱しない場合に比べヒスタチン類の収量が多い こと，およびヒスタチン類の構成比が一定になる 傾向があった。ヒスタチン類の構成比が一定にな 
らない傾向は，従来からとりわけ全唾液において 顯著であることが報告されていた ${ }^{25)}$ 。これは唾液 中に存在する種々のプロテアーゼなどによってヒ スタチン類が 口腔内において酵素的に分解を受け

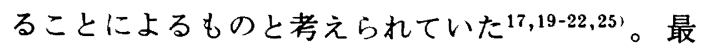
近, 顎下腺からのいわゆる塩基性 HRP の cDNA のクローニングによってその塩基配列から一次構

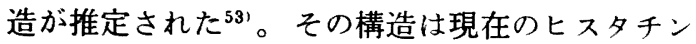
3 と一致するものであった。また, 耳下腺や顎下 腺からのヒスタチン 1 および 3 の cDNA の解析 から、これらの 2 種のヒスタチンが異なる遺伝子 から生成されること，および他のヒスタチン類は これら 2 種のヒスタチンから酵素的に分解を受け て生成されたものであると考えられている ${ }^{54-56)}$ 。 そこで著者は，酸性条件下で唾液試料を短時間加 熱することによって，分離時における口腔内のプ ロテアーゼの影響を極力少なくすることができ た。その結果，ヒスタチン 1 および 3 を収率よく 得ることができた。

したがって，本分離法は従来のヒスタチンの分 離法と比較して迅速性，再現性および収率におい て非常に有用であった。

現在までヒスタチン類には種々の生物活性が 報 告されているが，これらの活性について最初に記 載したのは Balekjian ら 24 であろう。彼らはう蝕 患者の耳下腺唾液を電気泳動することによって, 唾液中の塩基性の蛋白がう蝕のない患者と比較し て有意に少ないことを見いだした。これは後に

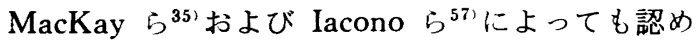
られたが，彼らの報告はいずれもヒスタチン類の 正確な同定および定量によって行われた結果では なかった。その後，ヒスタチン類の標品の精製が 可能になり，これらを用いて $S$. mutans に対す る抗菌作用および C. albicans に対する抗真菌作

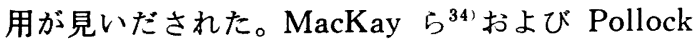
ら ${ }^{31}$ は, S. mutans や $C$. albicans をヒスタチ ン類の粗標品と保温することによって，ヒスタチ ン類が菌の増殖を阻止し，また高濃度では殺菌的 に㗢くことを見いだした。彼らはこのことから， ヒスタチン類が唾液中において自然の 殺菌成分と して存在している可能性を示唆した。その後, Oppenheim ら ${ }^{16,17)}$ は，精製したヒスタチン1，
3 および 5 を用いてそれぞれ C. alobicans の発芽 阻止作用および殺菌作用を見いだし，抗真菌作用 はヒスタチン 5 が最も強く, 次いでヒスタチン 3 , 1 の順であることを報告している。そして，この ことからヒスタチン類が免疫を介さない直接的な 生体防御機構 (host's non-immune defense system）に関与していることを示唆した。また Sanarpia III ら ${ }^{33)}$ も，精製したヒスタチン 5 が $C$. albicans に対して $\mathrm{pH}$ 依存性に静菌的または殺 菌的に作用することを報告している。

ヒスタチン類によるラット肥満細胞からの $\mathrm{Hi}$ 遊離活性は Sugiyama ら ${ }^{36}$ によって見いだされた が，彼らが分離したペプチドはヒスタチン 5 のみ であり，その他のヒスタチン類に関しての検討は なされていなかった。そこで本研究においては精 製したヒスタチン 1 および 3 に関してヒスタチン 5 と比較しながら $\mathrm{Hi}$ 遊離活性を検討した。

本研究におけるヒスタチン類によるラット肥満 細胞からの $\mathrm{Hi}$ 遊離に関して, 精製したヒスタチ ン 1 および 3 がヒスタチン 5 と同様に分離ラット 肥満細胞から脱顆粒を伴って用量依存的に $\mathrm{Hi}$ を 遊離することを確認した。この遊離反応はきわめ て短時間に完了し，温度や $\mathrm{pH}$ に著しく依存し ていた。しかし細胞外のカルシウムは必要ではな かった。またヒスタチン 5 による $\mathrm{Hi}$ 遊離に際し ては細胞質内の LDH の漏出は認められなかっ た。これらの結果は，ヒスタチン 5 によるラット 肥満細胞からの $\mathrm{Hi}$ 遊離が細胞外カルシウムに依 存しない開口分泌様式によるものであることを示 すものである。

肥満細胞からのペプチド類による $\mathrm{Hi}$ 遊離につ いては，サブスタンス $\mathrm{P}^{58) ， ニ ュ ー ロ テ ン シ ン 59) ， ~}$ ブラジキニン60)，ソマトスタチン61'拉よびダイ， ルフィン ${ }^{62}$ などの内因性ペプチドや, メリチン ${ }^{63)}$ およびポリミキシン $\mathrm{B}^{64)}$ などの 外因性ペプチドに ついて多くの報告がある。これらの多くは塩基性 のペプチドであり，また両親媒性の構造をもつも のが多い65)。これらぺプチドによる $\mathrm{Hi}$ 遊離反応 の共通点としては, 反応が瞬時に完了し, 温度と $\mathrm{pH}$ に依存性が強く, 細胞外カルシウムを必要と しないことである。これらは合成 $\mathrm{Hi}$ 遊離物質で ある compound 48/80による $\mathrm{Hi}$ 遊離と共通した 
機構によることが考えられる ${ }^{65)}$ 。 $\mathrm{Hi}$ 遊離活性の あるペプチドがその活性を示すための構造的な条 件としては, Lys, Arg および His などの塩基性 アミ，酸残基がその分子内に介在することが必須 であり，さらに分子内に疎水性の残基が局在する ことが活性を増強するものと考えられている ${ }^{45,86-}$ 68)。これらのペプチドの膜レベルでの反応機構と しては, 分子内の疎水性部分が肥満細胞の膜脂質 層に侵入し，次いで正の電荷を有する塩基性アミ ノ酸残基の部分が膜の負の電荷を示す部位と相互 作用を起こすことにより膜の攂乱を誘発し，脱顆 粒が惹起されることが示唆されている ${ }^{69,70) 。 ~}$

そこで $\mathrm{Hi}$ 遊離活性ペプチドの疎水性度と $\mathrm{Hi}$ 遊離活性の関係を知るために，八チ毒ペプチドで あるメリチンとヒスタチン 3 の疎水性度を Kyte と Doolittle のパラメータ ${ }^{21}$ に従って比較した (Fig. 10)。

メリチンは $\mathrm{C}$ 末端側に親水性の塩基性アミノ酸 残基を含み，その $\mathrm{N}$ 末端側には疎水性のアミノ酸 残基が局在する典型的な両親媒性のペプチドであ り，きわめて強い $\mathrm{Hi}$ 遊離活性を持つことが知ら

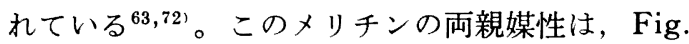
10に示寸ように疎水性度パラメータにより明らか であるが，ヒスタチン 3 はメリチンとは異なり， 完全に親水性のペプチドである。ヒスタチン 5 は ヒスタチン 3 の 1 ～24位までの構造と全く同じで あるため疎水性度は同程度と考えられる。また七 スタチン 1 に関してはヒスタチン 3 と比較して 構 造的に大きな差異は認められないが， 2 位の Ser に親水性のリン酸基が結合していることからヒス タチン 3 より若干親水性が強い傾向が 推察され る。

これらのことからヒスタチン 3 の疎水性度が 低 く，前述の脱顆粒モデルの条件を完全には満たし てはいないことがわかる。しかし本研究における ヒスタチン類による $\mathrm{Hi}$ 遊離機構は細胞外カルシ ウムに依存しないこと, 温度, $\mathrm{pH}$ への依存性, および反応の時間経過の類似性から一連のペプチ ド性の $\mathrm{Hi}$ 遊離物質と類似の機構によるものであ ることが推察される。それ故，ヒスタチン 3 とメ リチンとの疎水性度の比較から，ヒスタチン類に よる $\mathrm{Hi}$ 遊離は他の両親媒性のペプチドによる

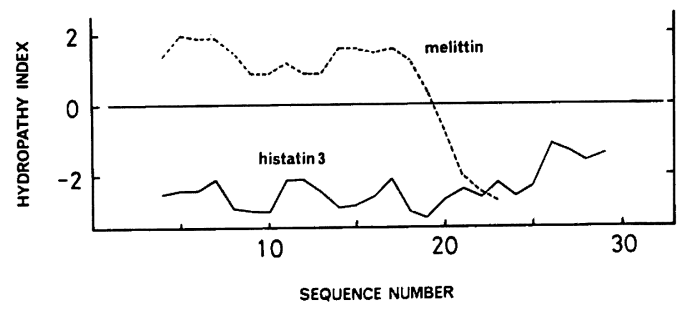

Fig. 10 Hydropathy profile of mellitin and histatin-3. Each plot indicates the mean value of hydropathy index of 7 residues according to the method of Kyte and Doolittle.

$\mathrm{Hi}$ 遊離と比較して厳密には膜レベルにおいて 機 構の異なる可能性も示唆される。

ヒスタチン 5 による $\mathrm{Hi}$ 遊離は温度依存性が強 く, 特に $10^{\circ} \mathrm{C}$ 以下および $45^{\circ} \mathrm{C}$ 以上の温度では 反応が抑制される。このことはおそらく肥満細胞 膜の流動性が関倸しており，流動性の低下寸る温 度では膜の粯乱が抑制されて反応性が低下するも のと思われる。膜の攪乱に関しては, ヒスタチン 類が膜の疎水性部分で $\alpha$-helix 構造をとることに よって起こるとされ，抗カンジダ活性もこの現象 が関係していると考えられている ${ }^{73)}$ 。

また,この $\mathrm{Hi}$ 遊離反応は溶液の $\mathrm{pH}$ が中性 側から酸性側で顕著にみられる。これはヒスタチ ン類がこれらの $\mathrm{pH}$ の範囲では解離型として存在 するために反応しやすい状態にあることが推察さ れる。

構造と活性相関についての詳細な解析は，ヒス タチン類の $\mathrm{Hi}$ 遊離に必須な活性部位 (essential moiety）を決定する必要がある。現在著者はヒス タチン類を種々の蛋白分解酵素などで分解して活 性部位の検索を行っているが，ヒスタチン 5 はヒ スタチン 3 の $\mathrm{N}$ 端 1 位から 24 位までの構造であ り，この二者の $\mathrm{Hi}$ 遊離活性の強さは同程度であ ることから， $\mathrm{Hi}$ 遊離活性に必要な分子構造は七 スタチン 5 の 分子中に存在することが示唆され る。また，ヒスタチン 1 は 2 位の Ser に結合した リン酸基によって活性が減弱されることが推察さ れる。このリン酸基の存在は, Oppenheim ら ${ }^{16)}$ のヒドロキシアパタイトに対する結合性に関与す る部位でもあるので， $\mathrm{Hi}$ 遊離活性の発現とは異 なっており興味深い。 
従来多くの研究がなされてきた $\mathrm{Hi}$ 遊離物質の 細胞レベルでの反応機構は，肥満細胞膜に与えら れた刺激情報が膜に存在するホスホリパーゼCを 活性化し，イノシトールリン脂質の代謝変化を引 き起こし，これによって細胞内の遊離カルシウム 濃度が上昇し，脱顆粒現象が惹起させることが示 唆されている(4)。最近, compound 48/80および トロンビンによる肥満細胞からの Hi 遊離が百日 咳毒素処理により著しく抑制されることが見いだ され，肥満細胞における $\mathrm{Hi}$ 遊離刺激によるホス ホリパーゼCの活性化に百日咳毒素感受性 $\mathrm{G}$ 蛋白 が関与する可能性が指摘されている ${ }^{75)}$ 。この現象 はサブスタンス Pや八チ毒マストパランにおいて も確認され ${ }^{76)}$, マストパランは人工脂質膜中で直 接 $\mathrm{G}$ 蛋白を活性化することが認められている ${ }^{77)}$ 。 この G蛋白は, IgE を介する $\mathrm{Hi}$ 遊離においては 関与しないことが明らかにされておりり ${ }^{78,791} ， \operatorname{IgE}$ を介さないペプチド性 $\mathrm{Hi}$ 遊離物質による非免疫 的刺激での $\mathrm{Hi}$ 遊離機構を解明するための重要な 知見であり，本研究のヒスタチン類による $\mathrm{Hi}$ 遊 離とこのG蛋白とがどのような関連性にあるのか

\section{興味樑い。}

ヒスタチン類の口腔生物学的意義に関してはま だ不明の点が多いが，七スタチン類が肥満細胞か ら遊離する $\mathrm{Hi}$ は，哺乳動物のほとんどすべての 臟器組織中に存在し, 特に肥満細胞や好塩基球の 顆粒内に多く貯蔵されている。そして本来は体内 に恒存する生理的作用物質の 1 つとみなされるが アレルギー反応や種々の刺激作用によって $\mathrm{Hi}$ が 遊離されると，毛細血管の拡張や，透過性を六進 させ,これに伴う浮腫や発赤, および知覚神経終 末の刺激による搔痒感や痛みを招来し炎症を惹起 することから急性炎症初期のケミカルメディエー ターと考えられている ${ }^{801}$ 。また一方でヒスタチン 類の mRNA は耳下腺と萼下腺にのみ存在するこ とが最近判明した ${ }^{55,811}$ 。これらのことからヒスタ チン類の口腔生物学的意義として，唾液中に特異 的に分泌される自然の生体防御物質として抗菌作 用，抗真菌作用を示すとともに口腔内の炎症の初 期過程に関与している可能性が示唆される。

\section{結論}

ヒト混合唾液からラット腹腔肥満細胞からの $\mathrm{Hi}$ 遊離活性を有するペプチドを分離し, それら の $\mathrm{Hi}$ 遊離機構に関して詳細に検討し, 以下の結 果を得た。

1）ヘパリンアフィニティークロマトグラフィ 一によりヒト唾液蛋白は 3 つの分画 $(\mathrm{A} ， \mathrm{~B}$ およ びC）に分かれ，そのうち B と Cの分画に $\mathrm{Hi}$ 遊 離活性が認められた。

2）逆相 HPLC を用いてヘパリンカラムB, C 分画から $\mathrm{Hi}$ 遊離活性を指標にして $\mathrm{H}-1,3$, および 5 の 3 つのピークを分離した。

3） H-1，3 および 5 のアミノ酸分析および一 次構造を測定した。これらのペプチドはそれぞれ 分子内にヒスチジン残基を 7 つ含んでおり，七ス タチン $1 ， 3$ および 5 と完全に一致する構造であ ることを確認した。

4） H-3 おょび 5 は分離ラット肥満細胞から $5 \sim 40 \mu \mathrm{M}$ の濃度範囲で脱顆粒を伴って用量依存 的に $\mathrm{Hi}$ を遊離した。これらの $\mathrm{ED}_{50}$ は両者共 ほぼ同じ值で約 $15 \mu \mathrm{M}$ であった。一方 $\mathrm{H}-1$ も $\mathrm{Hi}$ 遊離活性を示したが $\mathrm{ED}_{50}$ は $100 \mu \mathrm{M}$ であり，H-3 および H-5 に比べ活性は弱かった。

5） $\mathrm{H}-5$ による $\mathrm{Hi}$ 遊離は $37^{\circ} \mathrm{C}$ で10秒以内に 完了し, 至適温度は $25^{\circ} \mathrm{C} \sim 37^{\circ} \mathrm{C}$ の範囲であった。 反応温度が $15^{\circ} \mathrm{C}$ 以下および $45^{\circ} \mathrm{C}$ 以上では $\mathrm{Hi}$ 遊 離は抑制された。この遊離はメジウムの $\mathrm{pH}$ が 中性から酸性側で顕著に起こり，アルカリ側では 抑制された。またこの遊離はメジウム中のカルシ ウムを必要としなかった。

6） H-5 による $\mathrm{Hi}$ 遊離に際して肥満細胞から の乳酸脱水素酵素の漏出は認められなかった。

以上の結果は $\mathrm{Hi}$ 遊離を指標にして, ヘパリン アフィニティークロマトグラフィーと逆相 HP. LC によって迅速，簡便にヒト混合唾液からヒス タチン $1 ， 3$ および 5 を分離できることを示すも のである。またヒスタチン 5 は肥満細胞から細胞 外液のカルシウムに依存しない開口分泌様式によ って Hi を遊離することがわかった。おそらくヒ スタチン類は自然の生体防御物質として口腔内の 炎症の初期過程に何らかの役割を果たしているも 
のと考えられる。

謝辞：稿を終えるに嗄み，終始御愁䉆なる御指導なら びに御校閲を晹りました岡山大学歯学部㐘科薬理学教室 古田裕昭教授，杉山勝三助教授に深甚なる感韵の意を表 します。また本研究の機会を与えて下さり，御指導と御 校閲を晹った岡山大学歯学部口腔外科学第 1 蓝座西嶋克
巳教授に衣心から感謝致します。

さらに，本研究を進めるにあたり，終始御援助，御助 言いただきました歯科薬理学教室の皆様，ならびに口腔 外科学第 1 謮座の皆様に心から感謝致します。

本袷文の要旨は，第62回日本萩理学会総会（1989年 3 月，京都）において発表した。

抄録：ラット肥満細胞からのヒスタミン $(\mathrm{Hi})$ 遊離活性を有するペプチドをヒト唾液からヘパリンアフィ ニティークロマトグラフィーと逆相高速液体クロマトグラフィー（HPLC）を用いて分離した。

ヘパリンカラムからの唾液ペプチドの溶出分画は $\mathrm{A}, \mathrm{B}$ 拉よび $\mathrm{C}$ の 3つの分画に分かれ，そのうちBおよ びCの分画にヒスタミン遊離活性が認められた。これらの分画についてさらに逆相 HPLC で精製し，Hi 遊 離活性を持つ 3 つのピーク（H-1，3および 5 ) を得た。これらのピークのペプチドについてアミノ酸組成お よび一次構造を測定した。その結果 H-1，3および 5 はそれぞれヒスタチン $1 ， 3$ および 5 に一致していた。

$\mathrm{H}-3$ および $\mathrm{H}-5$ は $5 \sim 40 \mu \mathrm{M}$ の濃度範囲で分離ラット肥満細胞から脱顆粒を伴って濃度依存的に Hi を 遊離した。 $\mathrm{H}-1$ も $\mathrm{Hi}$ 遊離活性を示したが，その活性は H-3 や H-5 に比べて弱かった。 H-5によ.3 Hi 遊離は $37^{\circ} \mathrm{C}$ では 10 秒以内に最大に達し，その至適温度は $25^{\circ} \mathrm{C}$ から $37^{\circ} \mathrm{C}$ の範囲にあった。反応温度が $15^{\circ} \mathrm{C}$ 以下および $45^{\circ} \mathrm{C}$ 以上では遊離は抑制された。この遊離反応は溶液の $\mathrm{pH}$ が中性側から酸性側で顕著であり， アルカリ側では抑制された。また $\mathrm{Hi}$ 遊㕍反応はメジウム中のカルシウムを必要としなかった。H-5による $\mathrm{Hi}$ 遊﨎に際して肥満細胞からの LDH の漏出は認められなかった。以上の結果はヘパリンカラム法と逆相 HPLC の併用によってヒト唾液中からヒスタチン $1 ， 3$ 抢よび 5 を迅速に分離, 精製することができること， およびヒスタチン 5 が肥満細胞から細胞外液中のカルシウムに依存しない開口分泌様式によって Hi を遊離 することを示寸ものである。この $\mathrm{Hi}$ 遊離作用の生理的な意義は不明であるが自然の生体防御物質として口 腔内の次症の初期過程に関与しているものと考えられる。

\section{文献}

1) Mandel, I. D. : The role of saliva in main taining oral homeostasis. J. Am. Dent. Assoc. 119 : 298-304, 1989.

2) 市岡正道, 斉藤忠義, 河村洋二郎, 党道幸男, 坂田三弥編: 最新歯学生理学, 第 2 版, pp. 452-455, 医歯薬出版, 東京, 1983.

3) Hay, D. I. : CRC handbook of experimental aspects of oral biochemistry, pp. 319335, CRC press, Inc., Boca Raton, FL., 1983.

4）真田一男：唾液ペプチドの構造と口腔内におけ る機能. 歯科ジャーナル $16: 589-597,1982$.

5) Minaguchi, K. and Bennick, A.: Genetics of human salivary proteins. J. Dent. Res. $68: 2-15,1989$.

6) 久保木芳徳, 寺岡加代:歯質表面のアパタイトと 唾液タンパク質一う蝕征服の鍵. Quintessence 4: 27-36, 1985.

7) Hay, D. I. : The interaction of human parotid salivary proteins with hydroxyapatite. Arch. Oral Biol. 18 : 1517-1529, 1973.

8) Moreno, E. C., Kresak, M. and Hay, D.
I. : Adsorption thermodynamics of acidic proline-rich human salivary proteins onto calcium apatites. J. Biol. Chem. 257 : 29812989, 1982.

9) Hay, D. I.: The isolation from human parotid saliva of a tyrosine-rich acidic peptide which exhibits high affinity for hydroxyapatite surfaces. Arch. Oral Biol. 18: 15311541, 1973.

10) Hay, D. I. : Fractionation of human parotid salivary proteins and the isolation of an histidine-rich acidic peptide which shows high affinity for hydroxyapatite surfaces. Arch. Oral Biol. 20 : 553-558, 1975.

11) Miyake, M., Sanjo, O., Kuboki, Y. and Sasaki, S.: A histidine-rich protein isolated from human parotid saliva having a high affinity to hydroxyapatite. Jpn. J. Oral Biol. 29 : 477-481, 1987.

12) Bennick, A., Chau, G., Goodlin, R., Abrams, S., Tustian, D. and Madapallimattam, G. : The role of human salivary acidic proline-rich proteins in the formation of acquired dental pellicle in vivo and their fate 
after adsorption to the human enamel surface. Arch. Oral Biol. 28 : 19-27, 1983.

13) Schlesinger, D. H. and Hay, D. I. : Complete structure of statherin, a tyrosin-rich acidic peptide which inhibits calcium phosphate precipitation from human parotid saliva. J. Biol Chem. 252 : 1689-1695, 1977.

14) Hay, D. I., Bennick, A., Schlesinger, D. H., Minaguchi, K., Madapallimattam, G. and Schluckebier, S. K.: The primary struc tures of six human salivary acidic proline rich proteins (PRP-1, PRP-2, PRP-3, PRP 4, PIF-s, PIF-f). Biochem. J. $255:$ 15-21, 1988.

15) Bennick, A.: Structual and genetic aspects of proline-rich proteins. J. Dent. Res. 66 : 457-461, 1987

16) Oppenheim, F. G., Yang, Y.C., Diamond, R. D., Hyslop, D., Offner, G. D. and Troxer, R. F.: The primary structure and functional characterization of the neutral his tidine-rich polypeptide from human parotid secretion. J. Biol. Chem. 261 : 1177-1182. 1986.

17) Oppenheim, F. G., Xu, T., McMillian, F. M., Levitz, S. M., Diamond, R. D., Offner, G. D. and Troxler, R. F.: Histatins, a novel family of histidine-rich proteins in human parotid secretion. J. Biol. Chem. 263 : 7472-7477, 1988.

18) Troxler, R. F., Offner, G. D., Xu, T., vanderSpek, J. C. and Oppenheim, F. G. : Structual relationship between human salivary histatins. J. Dent. Res. $69: 2-6,1990$.

19) Azen, E. A.: Genetic polymorphism of basic proteins from parotid saliva. Science 176 : 673-674, 1972.

20) Azen, E. A.: Properties of salivary basic proteins showing polymorphism. Biochem. Genet. 9 : 69-86, 1973.

21) Peters, E. H. and Azen, E. A. : Isolation and partial characterization of human parotid basic proteins. Biochem. Genet. 15 : 925-946, 1977.

22) Peters, E. H., Goodfriend, T. and Azen, E. A.: Human $\mathrm{Pb}$, human post $\mathrm{Pb}$, and nonhuman primate $\mathrm{Pb}$ proteins : Immunological and biochemical relationships. Biochem. Genet. 15 : 947-962, 1977.

23) Balekjian, A. Y. and Longton, R. W. : Histones isolated from human parotid fluid. Biochem. Biophys. Res. Commun. 50 : 676$682,1973$.

24) Balekjian, A. Y., Meyer, T. S., Montague, M. E. and Longton, R. W. : Electrophoretic patterns of parotid fluid proteins from caries-susceptible individuals. J. Dent. Res. 54 : 850-856, 1975.

25) Baum, B. J., Bird, J. L., Millar, D. B. and Longton, R. W.: Studies on histidinerich polypeptides from human parotid saliva. Arch. Biochem. Biophys. 177 : 427-436, 1976.

26) Baum, B. J., Bird, J. L., Millar, D. B. and Longton, R. W.: Isolation and partial characterization of an histidine-rich polypeptide from parotid saliva of the monkey, macacanemestrina. Comp. Biochem. Physiol. 56A : 115-120, 1977

27) Baum, B. J., Bird, J. L. and Longton, R. W.: Histidine-rich-polypeptides in macaque parotid saliva are not nuclear histones. Arch. Oral Biol. 22 : 455-456, 1977.

28) Baum, B. J., Bird, J. L. and Longton, R. W.: Polyacrylamide gel electrophoresis of human salivary histidine-rich-polypeptides. J. Dent. Res. 56 : 1115-1118, 1977.

29) Baum, B. J., Bird, J. L. and Longton, R. W.: Evidence that the histidine-rich polypeptides of human parotid saliva are acinar secretory products of the parotid gland. J. Dent. Res. 56 : 877, 1977.

30) MacKay, B. J., Pollock, J. J., Iacono, V. J. and Baum, B. J. : Isolation of milligram quantities of a group of histidine-rich polypeptides from human parotid saliva. Infect. Immun. 44 : 688-694, 1984

31) Pollock, J. J., Denepitiya, L., MacKay, B. J. and Iacono, V. J. : Fungistatic and fungicidal activity of human parotid salivary histidine-rich polypeptides on Candida albicans. Infect. Immun. 44: 702-707, 1984.

32) Pollock, J. J., MacKay, B. J., Denepitiya, L., Iacono, V. J. and Renner, R. P. : Anticandida properties of natural salivary histidine-rich and synthetic histidine peptides: relevance to denture stomatitis, XXXIInd colloquium, protides of the biological fluids, pp. 309-314, Pergamon press, Oxford, 1984.

33) Santarpia III, R. P., Brant, E. C., Lal, K., Brasseur, M. M., Hong, A. L. and Pollock, J. J.: A comparison of the inhibition of blastspore viability and germ-tube development in Candida albicans by histidine peptides and ketoconazole. Arch. Oral Biol. 33 : 567-573, 1988.

34) MacKay, B. J., Denepitiya, L., Iacono, V. J., Krost, S. B. and Pollock, J. J. : Growthinhibitory and bactericidal effects of human parotid salivary histidine-rich polypeptides on Streptococcus mutans. Infect. Immun. 44 : 695-701, 1984.

35) MacKay, B. J., Iacono, V. J., Baum, B. 
J. and Pollock, J. J. : Effect of salivary cationic polypeptides on permeability of bacterial membranes. J. Dent. Res. (Abstr.) 58 : 256, 1979.

36) Sugiyama, K., Suzuki, Y. and Furuta, H. : Isolation and characterization of histaminereleasing peptides from human parotid saliva. Life Sci. 37 : 475-480, 1985.

37) Sugiyama, K., Miyoshi, S. and Furuta, H. : The amino acid sequence of a salivary peptide (F-A) with histamine-releasing property. Jpn. J. Oral Biol. 27 : 1252-1253, 1985.

38）久保木芳徳: 採唾法と唾液の生化学検查. 歯科 ジャーナル $16: 725-732,1982$.

39) Sugiyama, K.: Calcium-dependent histamine release with degranulation from isolated rat mast cells by adenosine 5'-triphosphate. Jpn. J. Pharmacol. 21 : 209-226, 1971.

40) Enerbäck, L. and Svensson, I. : Isolation of rat peritoneal mast cells by centrifugation on density gradients of percoll. J. Immunol. Methods 39 : 135-145, 1980.

41) Sugiyama, K., Ogino, T. and Ogata, K. : Histamine release induced by proteolytic digests of human serum albumin: Isolation and structure of an active peptide from pepsin treatment. Jpn. J. Pharmacol. 49 : 165-175, 1989.

42) Edman, P. and Begg, G.: A protein sequenator. Eur. J. Biochem. 1: 80-91, 1967.

43) Bloom, G. D., Fredholm, B. and Haegermark, Ö.: Studies on the time course of histamine release and morphological changes induced by histamine liberators in rat peritoneal mast cells. Acta Physiol. Scand. 71 : 270-282, 1967.

44) Shore, P. A., Burkhalter, A. and Cohn, V. H., Jr.: A method for the fluorometric assay of histamine in tissues. J. Pharmacol. Exp. Ther. 127 : 182-186, 1959.

45) Roy, P. D., Moran, D. M., Bryant, V., Stevenson, R. and Stanworth, D. R. : Further studies on histamine release from rat mast cells in vitro induced by peptides. Biochem. J. 191 : 233-237, 1980.

46) Hoerman, K. C. : On the zone electrophoresis of human parotid saliva in starch gels. J. Lab. Clin. Med. 53 : 64-68, 1959.

47) Meyer, T. S. and Lamberts, B. L.: Zone electrophoresis of human parotid saliva in acrylamide gel. Nature 205 : 1215-1216, 1965.

48) Bellavia, S. L. : Electrophoresis of proteins from human parotid saliva. Arch. Oral Biol. 16 : 751-758, 1971.

49) Bonilla, C. A. and Stringham, R. M., Jr. : Electrophoresis of human salivary secretions at acid pH. J. Chromatogr. $50: 345-348$, 1970.

50) Holbrook, I. B. and Molan, P. C. : The identification of a peptide in human parotid saliva particularly active in enhancing the glycolytic activity of the salivary micro-organisms. Biochem. J. $149:$ 489-492, 1975.

51）杉山勝三, 鈴木幸雄, 森画孝子, 古田裕昭 : 、 ウス額下腺のヒスタミン遊離物質に関する研 究. 歯基礎誌 26 : 1144-1151, 1984.

52) Sugiyama, K., Suzuki, Y. and Furuta, H. : Histamine-release induced by $7 \mathrm{~S}$ nervegrowth factor of mouse submandibular salivary glands. Arch. Oral Biol. 30 : 93-95, 1985.

53) Dickinson, D. P., Ridall, A. L. and Levine, M. J.: Human submandibular gland statherin and basic histidine-rich peptide are encoded by highly abundant mRNA's derived from a common ancestral sequence. Biochem. Biophys. Res. Commun. 149, 784-790, 1987.

54) Sabatini, L. M. and Azen, E. A.: Histatins, a family of salivary histidine-rich proteins, are encoded by at least two loci (HIS1 and HIS2). Biochem. Biophys. Res. Commun. 160 : 495-502, 1989.

55) vanderSpek, J. C., Offner, G. D., Troxler, R. F. and Oppenheim, F. G.: Molecular cloning of human submandibular histatins. Arch. Oral Biol. 35 : 137-143, 1990.

56) vanderSpek, J. C., Wyandt, H. E., Skare, J. C., Milunsky, A., Oppenheim, F. G. and Troxler, R. F.: Localization of the genes for histatins to human chromosome $4 \mathrm{q} 13$ and tissue distribution of the mRNAs. Am. J. Hum. Genet. 45 : 381-387, 1989.

57) Iacono, V. J., MacKay, B. J., Denepitiya, L., Pollock, J. J., Petropoulou, K. and Mandel, I. D. : Salivary histidine-rich polypeptide profiles of caries-resistant and -susceptible adults. J. Dent. Res. (Abstr.) 62 : 516, 1983.

58) Erjavec, F., Lembeck, F., Florjanc-Irman, T., Skofitsch, G., Donnerer, J., Saria, A. and Holzer, P.: Release of histamine by substance P. Naunyn-Schmied. Arch. Pharmacol. $317: 67-70,1981$

59) Carraway, R., Cochrane, D. E., Lansman, J. B., Leeman, S. E., Paterson, B. M. and Welch, H. J.: Neurotensin stimulates exocytotic histamine secretion from rat mast cells and elevates plasma histamine levels. J. Physiol. (Lond.) 323 : 403-414, 1982.

60) Devillier, P., Renoux, M., Giroud, J-P. and Regoli, D.: Peptides and histamine release from rat peritoneal mast cells. Eur. J. Phar- 
macol. $117: 89-96,1985$.

61) Theoharides, T. C. and Douglas, W. W. : Mast cell histamine secretion in response to somatostatin analogues: structural considerations. Eur. J. Pharmacol. $73: 131-136$, 1981.

62) Sugiyama, K. and Furuta, H.: Histamine release induced by dynorphin- (1-13) from rat mast cells. Jpn. J. Pharmacol. 35 : 247252, 1984.

63）杉山勝三, 古田裕昭 : 八チ毒による肥満細胞か らのヒスタミン遊離とセファランチンによる抑 制作用. 基礎と臨床 $18: 33-36,1984$.

64) Peachell, P. T. and Pearce, F. L. : Some studies on the release of histamine from mast cells treated with polymyxin. Agents Actions 14 : 379-385, 1984.

65) Lagunoff, D., Martin, T. W. and Read, G. : Agents that release histamine from mast cells. Ann. Rev. Pharmacol. Toxicol. 23 : 331-351, 1983.

66) Johnson, A. R. and Erdös, E. G. : Release of histamine from mast cells by vasoactive peptides, Proc. Soc. Exp. Biol. Med. 142 : 1252-1256. 1973.

67) Jasani, B., Kreil, G., Mackler, B. F. and Stanworth, D. R.: Further studies on the structual requirements for polypeptide-mediated histamine release from rat mast cells. Biochem. J. 181 : 623-632, 1979.

68) Foreman, J. C., Jordan, C. C., Oehme, P. and Renner, H.: Structure-activity relationship for some substance P-related peptides that cause wheal and flare reactions in human skin. J. Physiol. (Lond.) 335 : 449-465, 1983.

69) Repke, H., Piotrowski, W., Bienert, M. and Foreman, J. C.: Histamine release induced by Arg-Pro-Lys-Pro $\left(\mathrm{CH}_{2}\right){ }_{11} \mathrm{CH}_{3}$ from rat peritoneal mast cells. J. Pharmacol. Exp. Ther. 243 : 317-321, 1987.

70) Repke, H. and Bienert, M.: Structual requirements for mast cell triggering by substance P-like peptides. Agents Actions 23 : 207-210, 1988.

71) Kyte, J. and Dollittle, R. F.: A simple method for displaying the hydropathic char- acter of a protein. J. Mol. Biol. $157:$ 105132, 1982.

72) Habermann, E.: Bee and wasp venoms. Science $177: 314-322,1972$.

73) Raj, P. A., Edgerton, M. and Levine, M. J. : Salivary histatin 5 : dependence of sequence, chain length, and helical conformation for candidacidal activity. J. Biol. Chem. 265 : 3898-3905, 1990.

74）岡島史和 : GTP 結合蛋白質とイノシトールリ ン脂質代謝. 代謝 $25: 237-248,1988$.

75) Saito, H., Okajima, F., Molski, T. F. P., Sha'afi, R. I., Ui, M. and Ishizaka, T.: Effects of ADP-ribosylation of GTP-binding protein by pertussis toxin on immunoglobulin E-dependent and -independent histamine release from mast cells and basophils. J. Immunol. 11 : 3927-3934, 1987.

76) Mousli, M., Bronner, C., Bueb, J-L., Tschirhart, E., Gies, J-P. and Landry, Y.: Activation of rat mast cells by substance $P$ and mastparan. J. Pharmacol. Exp. Ther. 250 : 329-335, 1989.

77) Higashijima, T., Uzu, S., Nakajima, T. and Ross, E. M.: Mastoparan, a peptide toxin from wasp venom, mimics receptors by activating GTP-binding relulatory proteins (G proteins). J. Biol. Chem. 263 : 6491-6494, 1988.

78) Saito, H., Okajima, F., Molski, T. F. P., Sha'af, R. I., Ui, M. and Ishizaka, T.: Effect of cholera toxin on histamine release from bone marrow-derived mouse mast cells. Proc. Natl. Acad. Sci. USA. 85 : 25042508, 1988.

79) Ishizaka, T.: Role of GTP-binding protein in histamine release from mast cells. Clin. Immunol. Immunopathol. 50 : 20-29, 1989.

80）木村義民：ヒスタミン研究の史的展望と近年の 知見. 治療学 $18: 147-149,1987$.

81) Sabatini, L. M., Warner, T. F., Saitoh, E. and Azen, E. A.: Tissue distribution of RNAs for cystatins, histatins, statherin, and proline-rich salivary proteins in humans and macaques. J. Dent. Res. 68 : 1138-1145, 1989. 